\title{
Assessing the Vulnerability of Public-Supply Wells to Contamination: Edwards Aquifer Near San Antonio, Texas
}

The U.S. Geological Survey's National Water-Quality Assessment (NAWQA) Program found, in studies from 1991 to 2001, low levels of mixtures of contaminants in groundwater near the water table in urban areas across the Nation. Contaminants were detected less frequently in deeper groundwater typically developed for public supply (Hamilton and others, 2004). The proximity of contaminant mixtures to underlying public water-supply sources, however, prompted the NAWQA
Program to begin intensive studies in 2001 to assess the vulnerability of publicsupply wells to contamination. Specifically, pathways and processes by which contaminants reach public-supply wells in nine aquifer systems across the country are being investigated. Scientists are studying the processes that occur below land surface - whereby contaminants are mobilized or attenuated — as well as investigating how human activities can affect the vulnerability of public-supply wells to contamination.
This fact sheet highlights findings from the vulnerability study of a public-supply well field in San Antonio, Texas (Lindgren and others, 2011a; Musgrove and others, 2011). The well field consists of six production wells that tap the Edwards aquifer. Although a single well was initially selected for study, constraints of well-field operation made it necessary for samples to be collected from different wells within the well field for various components of the study. Individual wells have a pumping capacity of
The Edwards aquifer in south-central Texas is composed primarily of limestone and dolostone deposited in a shallow marine environment; it is one of the most productive aquifers in the United States. Most water entering the Edwards aquifer originates from streams that drain the uplifted Edwards Plateau (also called the contributing zone or catchment area) to the west and north of San Antonio. As these streams flow across the Balcones fault zone, where porous rocks of the Edwards aquifer are exposed at land surface, much of the streamflow recharges the aquifer by infiltrating through fractures and karst features (caused by dissolution of bedrock). Precipitation that falls between the streams in the recharge zone also infiltrates into the aquifer, moving rapidly along karst features and faults. A relatively small amount of water flows into the Edwards aquifer from the adjacent and underlying Trinity aquifer.

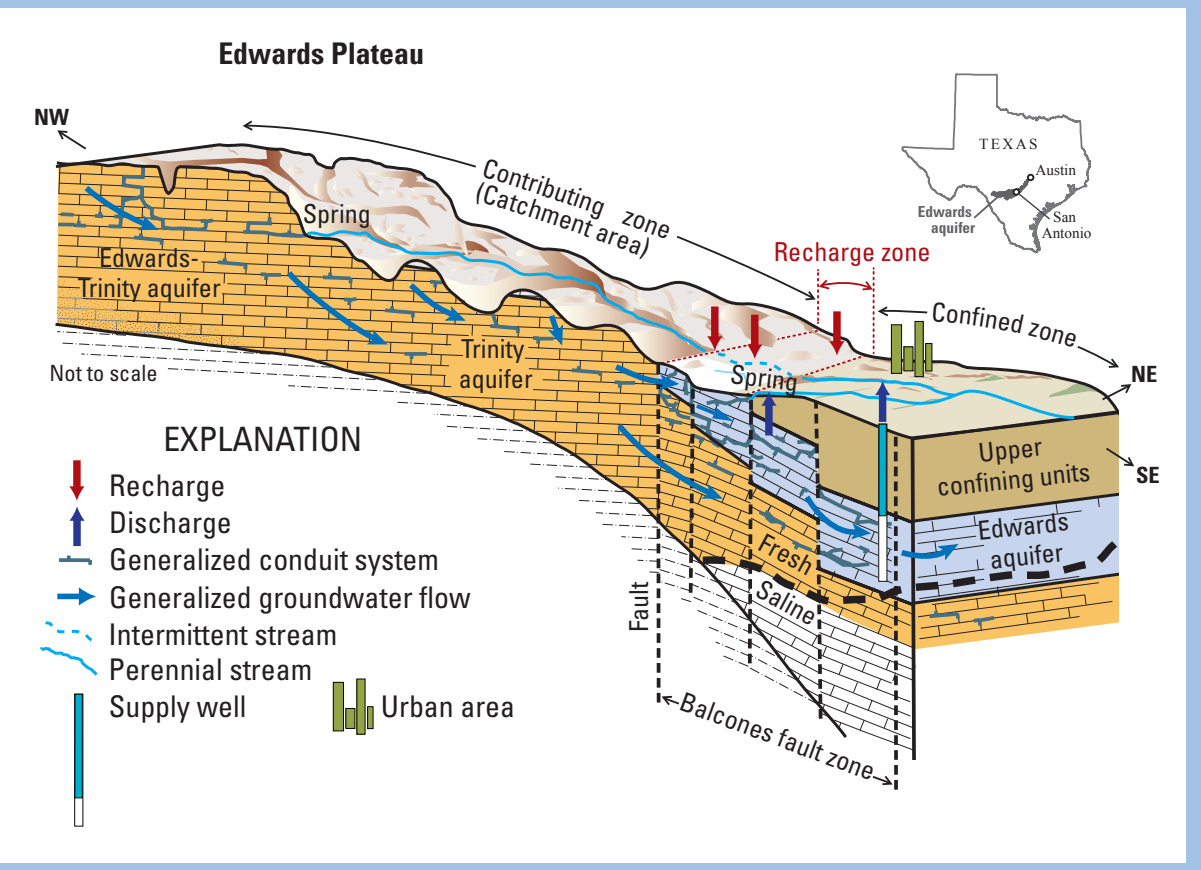

Once recharge reaches the Edwards aquifer,

it typically moves downward and laterally in a southeasterly direction, into the part of the system that is overlain by rocks of the upper confining units. Fine-grained, clay-rich layers in the upper confining units isolate this part of the Edwards aquifer from sources of vertical recharge. Groundwater in the Edwards aquifer encounters high-angle faults as it moves downgradient. Some of these faults might act as an impediment to flow, where layers of less permeable rock have been downdropped and now abut layers of the aquifer, and some faults may act as conduits for flow. Groundwater flow in the confined zone turns to the northeast, toward discharge areas at large springs between San Antonio and Austin. Flow is parallel to the southwest-to-northeast orientation of many of the faults. In some areas, these faults have been widened by dissolution, creating conduits and linear zones of increased permeability through which water can move rapidly.

In addition to natural discharge at springs, discharge from the Edwards aquifer occurs as groundwater withdrawals from wells, primarily for municipal, industrial, and irrigation water supply. Annual discharge by wells more than tripled between 1939 and 2000 in the San Antonio region. Increased pumping has affected springflow at some springs over time, but no long-term declines in groundwater levels have been observed. 
about 8,000 to 14,000 gallons per minute; typically, one or two wells are pumped at a time, yielding an average of 20-21 million gallons per day from the well field. In construction and operation, the wells studied are representative of many public-supply wells that tap the Edwards aquifer across the region (although not all wells in the region produce as much water as those in the selected well field). Land use in the study area is dominantly rangeland and forest, with a lesser amount of urban/built-up land (mostly in the San Antonio metropolitan area) and minor amounts of agriculture. Increasing population is causing ongoing urban growth.

Samples collected by USGS personnel in 2004 and 2005 from a publicsupply well in the selected well field contained some constituents of concern for drinking-water quality, including nitrate; the pesticide compounds atrazine, deethylatrazine, and simazine; and the volatile organic compounds (VOCs) tetrachloroethene (also known as perchloroethene, or PCE), chloroform, bromoform, and dibromochloromethane. These constituents were detected in untreated water at concentrations much less than established drinking-water standards, where such standards exist. Uranium, radon, and arsenic also were detected, but at concentrations that were not of concern with respect to drinking-water standards.

Most of the constituents of concern detected in the selected well field are anthropogenic (introduced by human activity). A database of potential sources of contaminants (Texas Commission on Environmental Quality, 2006) indicates that most potential sources of atrazine, PCE, and chloroform in the study area are in the San Antonio urban area. Potential sources of atrazine include sites of manufacture, sales, or application of pesticides to lawns and commercial properties. PCE is commonly used as a solvent in industrial and commercial facilities and at dry cleaners. Chloroform, bromo-

\section{Study Design}

Computer models of groundwater flow and transport were constructed at a regional scale (about 16,185 square miles) to estimate the "zone of contribution" to one of the public-supply wells (W3) in the selected well field (Lindgren and others, 2011b). The zone of contribution is the three-dimensional volume of the aquifer material through which groundwater flows from the time it enters the groundwater system at the water table in the recharge zone until it eventually discharges at the public-supply well. A total of six monitoring wells were installed at different depths in two well clusters along general directions of flow to W3 to understand groundwater movement and geochemical processes close to the well. Water samples were collected from the six monitoring wells, W3, and additional publicsupply wells in the well field during 2007 through 2009. Samples were analyzed for naturally occurring contaminants (such as uranium and arsenic) and anthropogenic contaminants (such as VOCs, pesticides, and nutrients). Other water-quality constituents (such as major ions, age-dating tracers, and selected isotopes) were analyzed for to improve understanding of sources of water and reactions affecting the chemical composition of groundwater. Analytical results were compared to regional water quality evaluated at 39 public-supply wells in 2004 and 2005 (Musgrove and others, 2011). Additional water samples were collected from public-supply well W4 in the well field at three depth intervals that correspond to three zones of high flow in the well (shallow, 380 feet; intermediate, 430 feet; and deep, 540 feet) under three different pumping conditions to determine where water and contaminants enter the well and to assess the effect of pumping on water quality (Musgrove and others, 2011). To assess short-term temporal variations in water quality, selected monitoring wells and W4 were sampled several times in response to a rainfall and recharge event. Finally, a detailed, local-scale (1,640-square-mile) computer model of steady-state groundwater flow and transport to W4 was constructed and calibrated to water levels, tritium concentrations, and spring discharge (Lindgren and others, 2011a). On the basis of existing information and preliminary flow measurements, two regionally extensive horizontal zones were included in the model that more readily transmit water than the surrounding aquifer materials - one in the leached and collapsed members of the Edwards aquifer and one in the Kirschberg evaporite member (fig. 1). These highly transmissive zones represent fast flow paths created by dissolution of bedrock. The local-scale model was used to calculate the traveltime of water particles entering W4 and to forecast water-quality changes that might be expected if a contaminant were released to the water table in the area contributing recharge to this well (Musgrove and others, 2011).

form, and dibromochloromethane can be formed as byproducts of drinking-water chlorination. Publicly supplied water containing chlorination byproducts may enter the groundwater system by way of leaking pipes, lawn irrigation, or use of treated water as a supply-well pump lubricant. Other sources of chloroform include metal plating and some manufacturing facilities. Nitrate may come from human sources (including fertilizers, septic system leachate, and leaking

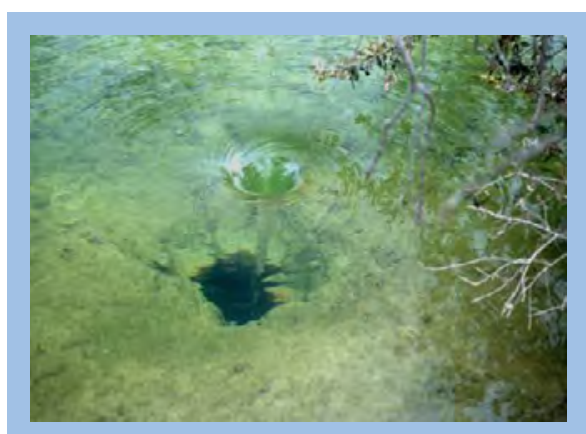

The vortex in this stream is caused by rapid drainage of water through a 2-foot-diameter karst feature in the streambed. Streams crossing the recharge zone of the Edwards aquifer lose much of their flow as water rapidly infiltrates to the water table along dissolution features such as this one. (Photo by David Johns, City of Austin, used with permission.)

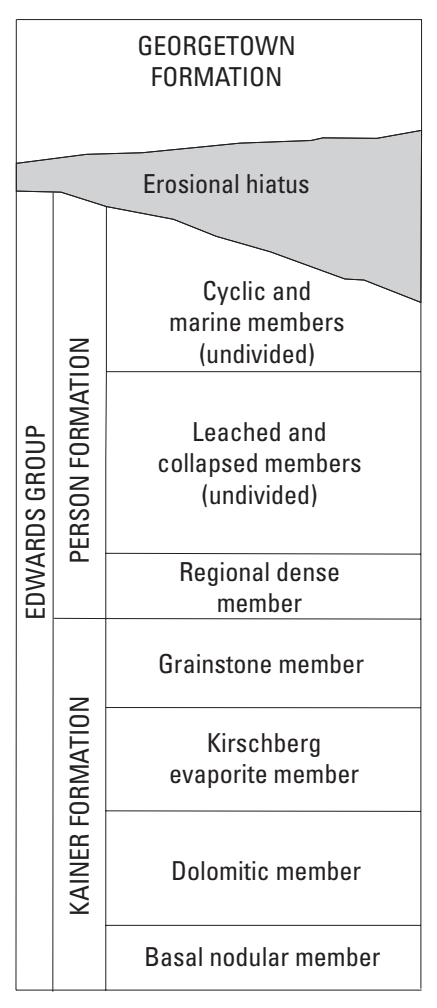

Figure 1. Stratigraphy (rock layers) of the Edwards aquifer in the San Antonio area (modified from Maclay, 1995). 
sewerlines) and natural sources (such as nitrogen in soil and animal waste) in the study area. Uranium, radon, and arsenic occur naturally in the rocks that make up the aquifer in the area.

Overall, the study findings point to four primary factors that affect the movement and fate of contaminants and the vulnerability of the public-supply well field in San Antonio, Texas: (1) groundwater age (how long ago water entered, or recharged, the aquifer), (2) fast pathways for flow of groundwater through features formed or enlarged by dissolution of bedrock, (3) recharge characteristics of the aquifer, and (4) natural geochemical processes within the aquifer. Study findings are intended to help water managers, drinking-water suppliers, and policymakers understand how and why contamination of public-supply wells occurs and anticipate whether water quality will improve or degrade. Additionally, study findings may be used in evaluating various aquifer-development and land-management scenarios.

\section{Well Vulnerability Results from Very Young Age of Groundwater}

Groundwater age refers to the elapsed time since water entered an aquifer at the water table. Because water in an aquifer typically flows downward and laterally over time, it is expected that the very youngest water will be found near the water table and older water will be found at greater depths. Groundwater age can be estimated by measuring concentrations of chemical tracers. Ratios of two such age tracers - tritium and its decay product, helium-3 - were measured at five monitoring wells, at four well-field public-supply wells, and in samples from shallow, intermediate, and deep depths in supply well W4 (fig. 2). Results indicate that groundwater in the well field and about 1.5 miles upgradient is generally young, recently recharged water $(<1$ to 41 years old) throughout most of the thickness of the aquifer. Unlike most aquifer settings, water age does not increase with depth near the well field.

Tritium:helium-3 ratios yield an "apparent" groundwater age that is most reliable for samples that are collected from a discrete depth interval in the aquifer (for example, from wells with a very short well screen). However, the long open interval of a public-supply well (about 500 feet in the selected well field) typically captures a mixture of water that recharged at different times. For such wells, some of the water entering the well will be younger and some of it will be older than what is indicated by a single, apparent (tracer-based) age estimate. To better understand the blend of water of different ages produced by the publicsupply well, a computer-model simulation of groundwater flow and transport was used to estimate the traveltime (or age) of water particles entering publicsupply well W4 along the length of the open interval. Modeled findings show that the simulated ages of particles reaching the well range from less than 1 day to 342 years (fig. 3 ), with a mean age of 4 years. Insight into well vulnerability can be gained from considering both the longest and shortest traveltimes to the well. Less than 1 percent of the water entering the well is 50 or more years old; water in this age range recharged the aquifer before the use of manmade chemicals became prevalent. Such a small percentage of old groundwater offers little potential for dilution of young water containing contaminants from human activities, should changes in land use degrade the quality of water recharging the aquifer in the future.

A more immediate vulnerability is indicated by the shortest traveltimes to the well. Figure 3 shows that almost half

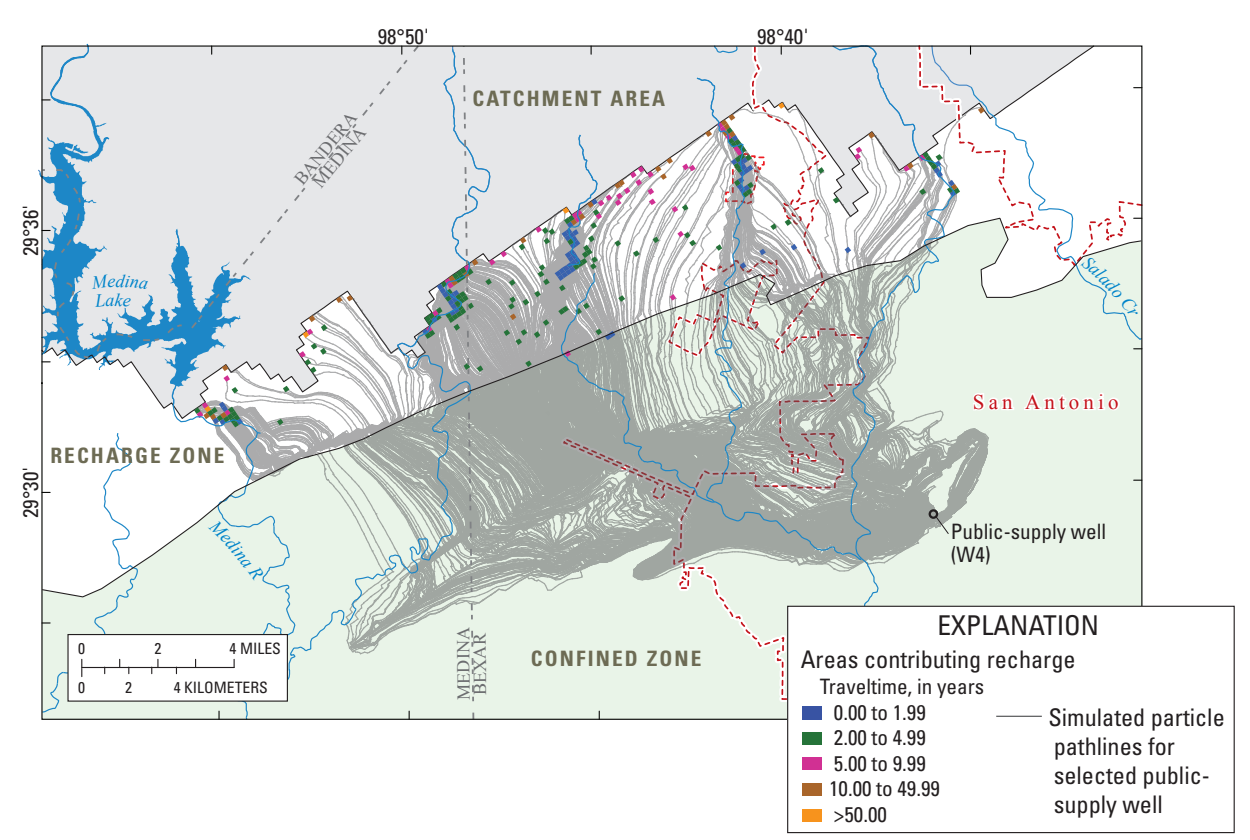

Figure 2. The colored zones on the map show the simulated areas contributing recharge
to a public-supply well selected for investigation in San Antonio, Texas. These colored zones
indicate where water that eventually reaches the public-supply well enters the groundwater
system at the water table.

Figure 2. The colored zones on the map show the simulated areas contributing recharge
to a public-supply well selected for investigation in San Antonio, Texas. These colored zones
indicate where water that eventually reaches the public-supply well enters the groundwater
system at the water table.

Figure 2. The colored zones on the map show the simulated areas contributing recharge
to a public-supply well selected for investigation in San Antonio, Texas. These colored zones
indicate where water that eventually reaches the public-supply well enters the groundwater
system at the water table.

Figure 2. The colored zones on the map show the simulated areas contributing recharge
to a public-supply well selected for investigation in San Antonio, Texas. These colored zones
indicate where water that eventually reaches the public-supply well enters the groundwater
system at the water table.

of the water reaching the public-supply well is less than 2 years old. Such a large percentage of very young water indicates that (a) contaminants entering the aquifer may be transported rapidly to the well, (b) there is limited time for chemical reactions to occur in the aquifer that may attenuate contaminants, and (c) should recharge water become contaminated with pathogenic microorganisms (which have limited survival times in aquifers), the microorganisms may be able to persist to the well.

\section{Karst Features Serve as Fast Pathways for Movement of Contaminants to the Public- Supply Well}

Geophysical logging and flowmeter measurements in public-supply well W4 in the well field and in nearby monitoring wells showed that most of the flow volume into and out of the wells occurs in three horizontal zones that correspond to regional stratigraphic units (fig.1) - a shallow zone at the top of the cyclic and marine members, an intermediate zone in the leached and collapsed members, and a deep zone in the Kirschberg evaporite member. These high-flow zones are likely areas where karst dissolution has enlarged bedding planes. Flow rates are also higher in these zones. The mean simulated particle age for water entering the well through the high-flow zones is 
3.8 years, whereas the mean simulated particle age for water entering the well through the aquifer matrix is 9.6 years.

Rapid flow of water through dissolution-enlarged pathways is further evidenced by fluctuations in groundwater chemistry that can be correlated to individual precipitation events. With rain, concentrations of nitrate in public-supply well W4 decrease as they are diluted by recharging stream water. Conversely, concentrations of PCE increase (at the selected well field), likely because of accelerated movement of water from an upgradient source to the well.

Simulated traveltimes in the area contributing recharge to the public-supply well are shown in figure 2. The colored zones on the map indicate where water that eventually reaches the public-supply well enters the groundwater system at the water table. Although the exact locations of these zones are unknown due to uncertainty in the location and connectivity of sinkholes, conduits, and other solution features, the simulated pattern of recharge is realistic given that such features allow most of the water reaching the well to travel rapidly from the recharge zone to the supply well along fast pathways rather than through the aquifer matrix. Simulated recharge to the well originates as far as 16 miles from the well, yet most of the water reaches the well in less than 5 years (fig. 3 ).

\section{Aquifer Recharge Characteristics Affect Movement of Contaminants to the Public-Supply Well}

Analysis of water samples collected from shallow, intermediate, and deep zones of the Edwards aquifer at publicsupply well W4 in the well field and from nearby monitoring wells revealed that water in the vicinity of the selected well field is notably well mixed throughout the sampled thickness of the Edwards aquifer, showing little of the chemical variation with depth that is commonly seen in other aquifers. Contaminants were found at all depths, and they did not enter the well through a specific horizon. Thus, although flowmeter measurements in the publicsupply well indicated that pumping of different wells or combinations of wells in the well field affects zones or horizons from which the largest volumes of water enter the well (Musgrove and others,

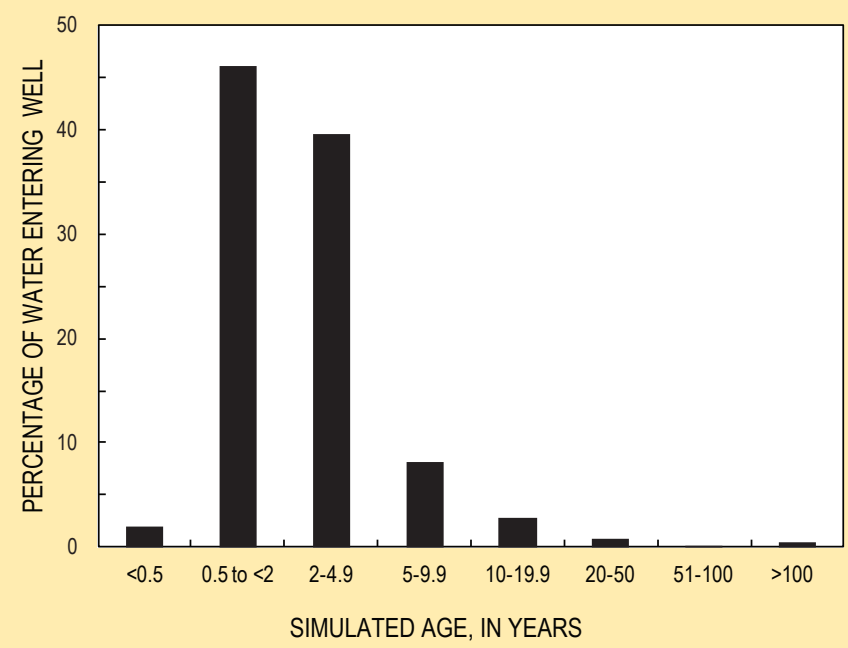

Figure 3. A groundwater-flow model was used to simulate the mixture of water of different ages produced by the selected public-supply well in San Antonio. "Water age" refers to the elapsed time between water entering the groundwater system at the water table in the recharge zone and arrival at the well. The young age of groundwater entering the well from deep parts of the aquifer (540 feet below land surface) is unusual relative to other types of aquifers and is attributed to the way water recharges the aquifer combined with rapid travel of large volumes of groundwater through fractures, faults, and bedding planes enlarged by dissolution.

2011), concurrent water-quality sampling documented that this does not appreciably affect contaminant concentrations discharged from the well.

The well-mixed nature of the Edwards aquifer is caused by the recharge characteristics of the area combined with fast flow paths through karst features: (1) recharge enters the Edwards aquifer directly, without infiltrating through overlying, chemically dissimilar rock units or thick soils (soils in the recharge zone are very thin); (2) recharging water (and any contaminants present in this water) can travel to depth in the aquifer rapidly through preferential flow paths, such as dissolution-enlarged faults, fractures, and bedding planes; and (3) the large volume of recharge (due to ongoing streamflow contribution combined with periodic precipitation) and steep hydraulic gradient (as much as 100 feet per mile) between the recharge area and the confined part of the aquifer causes water to flush rapidly through the conduits and other dissolution features in the aquifer. The intersection of high-flow zones combined with the higher-than-average pumping volumes of the selected well field likely induces more mixing and perhaps shorter traveltimes than are found elsewhere in the aquifer. This is suggested by a greater proportion of old water in some regional wells than was found in the studied wells (as simulated with the local-scale flow model), as well as by increased ratios of magnesium:calcium and strontium:calcium with depth in regional wells that were not seen in the studied wells. These higher ratios indicate greater contact time of groundwater with aquifer rocks along deeper, longer flow paths.

\section{Natural Geochemical Processes in the Aquifer Affect the Fate of Contaminants}

Geochemical conditions, such as the oxygen content of groundwater, control whether specific contaminants are attenuated or mobilized once they enter the groundwater system. In the oxic conditions found throughout the Edwards aquifer (dissolved oxygen concentrations of at least $1 \mathrm{mg} / \mathrm{L}$ (milligram per liter)), the anthropogenic contaminants nitrate, PCE, chloroform, bromoform, and dibromochloromethane will not readily degrade and can persist over long distances. Other contaminants are attenuated in the oxic conditions that are present throughout the aquifer. Atrazine degrades to deethylatrazine, but the detection of both compounds in the studied public-supply wells indicates that short traveltimes relative to atrazine degradation rates in the aquifer do not allow for complete degradation of the pesticide before it reaches the publicsupply wells. 


\section{Implications for Aquifer Protection}

Human activities in the recharge zone and catchment area (contributing zone) have the potential to affect water quality. Because most water enters the Edwards aquifer in the recharge zone, management of activities (such as urban development or industrial activities) that might degrade water quality in this area is recognized as essential for protecting the quality of drinking water produced by public-supply wells that tap the aquifer, especially given the short estimated traveltimes. Of equal importance is the protection of stream-water quality in the Edwards Plateau catchment area, because these streams provide most of the recharge to the aquifer as they flow across the recharge zone. The vulnerability of the Edwards aquifer to degradation of water quality was recognized in 1970, when the first regulations were implemented to protect the recharge zone and buffer zones (Texas Commission on Environmental Quality, 2011). Today, the "Edwards Aquifer Protection Program" is codified into State law to safeguard both water quality and water quantity in the aquifer (Texas Administrative Code, 2011). The Edwards Aquifer Authority, established in 1993, assists the Texas Commission on Environmental Quality (TCEQ) protection efforts in the San Antonio region. The TCEQ and Edwards Aquifer Authority have regulatory responsibilities regarding activities that could potentially affect surface- and recharge-water quality within the aquifer recharge zone and catchment area (Texas Commission on Environmental Quality, 2011; Edwards Aquifer Authority, 2011). The protection programs of these agencies include such requirements as identification and protection of sensitive karst features, implementation of best management practices for mitigating stormwater quality, limitations for activities associated with potential pollutants, and requirements for well construction or plugging of abandoned wells. Some water purveyors have additional watershedprotection and (or) wellhead-protection measures. Although protection mechanisms are in place, data from the Edwards aquifer indicate that anthropogenic activities have affected water quality: nitrate concentrations have increased over recent decades, and anthropogenic contaminants are more frequently detected in shallow urban wells (Musgrove and others, 2010).

A recent study by Mahler and others (2011) (in a location about 80 miles northeast of the well-field study area) documented the degradation to groundwater quality that can occur due to rapid urban development in areas supplying recharge to the Edwards aquifer. Nitrate concentrations in Barton Springs (a groundwater discharge point in Austin) and the streams that provide recharge in the catchment area for the springs have increased in recent years, in part because of increased nitrogen loading caused by rapid development in the recharge zone (fig. 4). Isotopic analysis indicates that a likely source of some of the nitrate is human or animal waste. "Increases in nitrate concentrations coincide with rapid increases in the number of septic systems and volume of land application of treated wastewater" in the parts of the catchment area and recharge zone that supply water to Barton Springs (Mahler and others, 2011). Although nitrate concentrations are still well below public drinking-water standards in the Barton Springs area and in the well-field study area, a trend of increasing nitrate concentration is cause for concern in an aquifer in which nitrate does not readily degrade.

Contaminant concentrations in the public-supply well will respond rapidly to changes in land use in the recharge zone and catchment area. Constituents of concern in the Edwards aquifer for the long-term sustainability of the groundwater resource include the nutrient nitrate and anthropogenic contaminants such as atrazine, PCE, and chloroform. A scenario of hypothetical contaminant loading was evaluated by using results from groundwater-flow-model particle tracking to assess the response of the aquifer to potential contamination. Contaminant concentrations in the publicsupply well over time are a result of (1) the mixture of ages of water reaching the well combined with (2) variation in contaminant inputs at land surface over time related to changing land use, and (3) degradation rates in the oxic environment of the Edwards aquifer. The effect of these three factors on concentrations of a hypothetical contaminant in public-supply well W4 was estimated by using the age mixture of water produced by the well as simulated by the local-scale groundwater model (fig. 3). The input concentration of a hypothetical contaminant applied to the water table in the area contributing recharge to the well was held constant for 30 years and then ceased. Figure 5 shows the response of the public-supply well to the simulation with no contaminant degradation and a simulation with degradation at a rate of 10 percent per year. Results indicate that the concentrations at the public-supply well would begin to respond to contaminant loading in the recharge zone within 1 year because of short traveltimes through fast flow paths. Within 10 years, contaminant concentrations in the public-supply well would be equal to 90 percent of the input concentration for a contaminant (such as nitrate) that does not degrade in the oxic

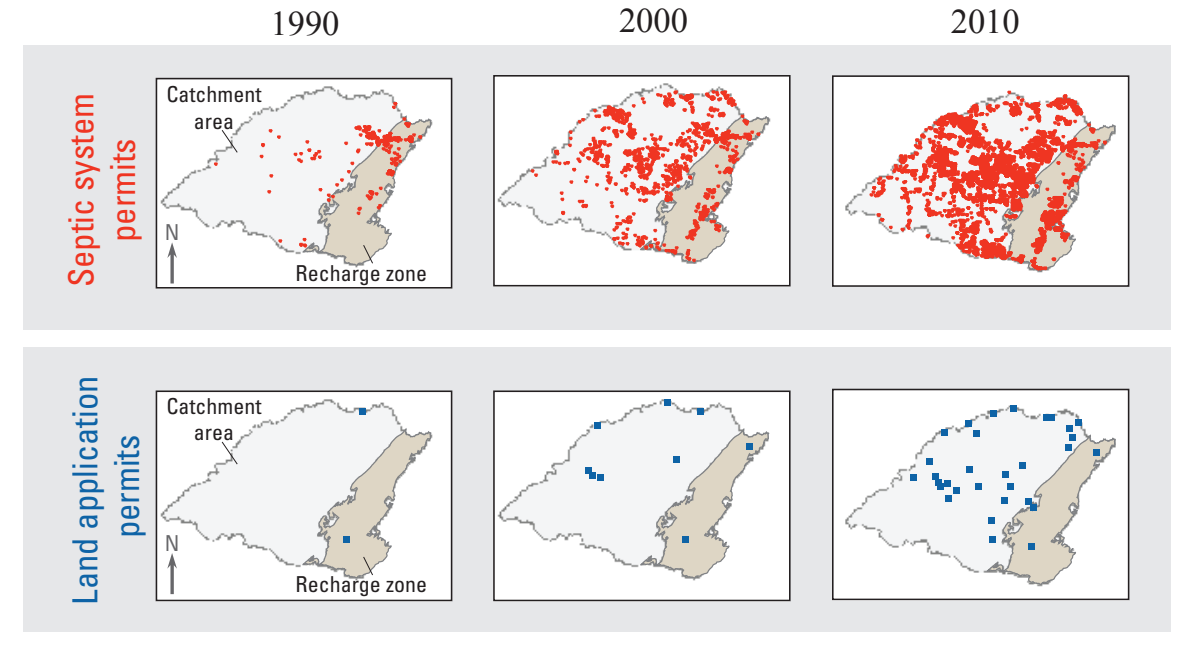

Figure 4. Permits for septic systems and land application of treated wastewater in the Barton Springs catchment area and recharge zone have increased greatly in recent years (modified from Mahler and others, 2011). 
conditions of the Edwards aquifer. For a contaminant that would degrade (such as atrazine), maximum concentrations at the supply well would eventually equal about 70 percent of the input concentration (if degradation occured at the simulated rate). The aquifer also would respond quickly (less than 1 year to several years) to the removal of contaminant loading; however, it would take decades to reach near-background concentrations.

\section{References}

Edwards Aquifer Authority, 2011, Policies and Rules, accessed August 24, 2011, at http://www.edwardsaquifer. org/display_policies_rules.php.

Hamilton, P.A., Miller, T.L., and Myers, D.N., 2004, Water quality in the Nation's streams and aquifers - Overview of selected findings, 1991-2001: U.S. Geological Survey Circular 1265, 20 p.

Lindgren, R.J., Houston, N.A., Musgrove, M., Fahlquist, L., and Kauffman, L.J., 2011a, Simulations of groundwater flow and particle-tracking analysis in the zone of contribution to a public-supply well in San Antonio, Texas: U.S. Geological Survey Scientific Investigations Report 2011-5149, 93 p.

Lindgren, R.J., Houston, N.A., Musgrove, M., Fahlquist, L., and Kauffman, L.J., 2011b, Hydrogeologic setting and groundwater flow simulations of the south-central Texas regional study area, Texas, section 3 of Eberts, S.E., ed., Hydrogeologic settings and groundwater flow simulations for regional studies of the transport of anthropogenic and natural contaminants to public-supply wells: U.S. Geological Survey Professional Paper 1737-B, 51 p.

Maclay, R.W., 1995, Geology and hydrology of the Edwards aquifer in the San Antonio area, Texas: U.S. Geological Survey Water-Resources Investigations Report 95-4186, 64 p.

Mahler, B.J., Musgrove, M., and Herrington, C., 2011, Nitrate concentrations and potential sources in the Barton Springs segment of the Edwards aquifer and its contributing zone, central Texas: U.S. Geological Survey Fact Sheet 2011-3035, 4 p.

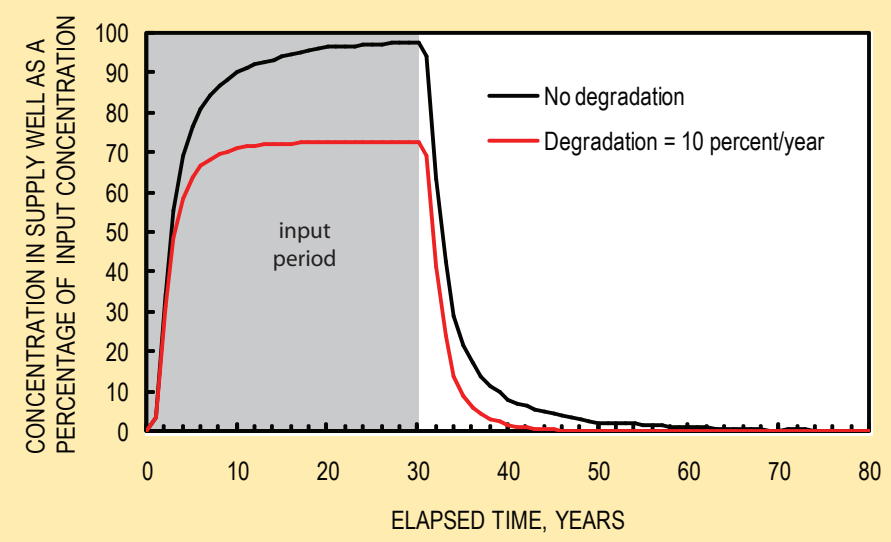

Figure 5. On the basis of simulated groundwater flow and particle-tracking results, the response of the modeled public-supply well to the hypothetical input (over a 30-year period) of a contaminant in the area contributing recharge to the well was examined. Within 10 years, concentrations in water withdrawn from the well would be equal to about 90 percent of the input concentration, if the contaminant were stable in the oxic conditions of the aquifer (as is the case for nitrate).
Musgrove, M., Fahlquist, L., Stanton, G.P., Houston, N.A., and Lindgren, R.J., 2011, Hydrogeology, chemical characteristics, and water sources and pathways in the zone of contribution of a public-supply well in San Antonio, Texas: U.S. Geological Survey Scientific Investigations Report 2011-5146, 194 p.

Musgrove, M., Fahlquist, L., Houston, N.A., Lindgren, R.J., and Ging, P.B., 2010, Geochemical evolution processes and water-quality observations based on results of the National WaterQuality Assessment Program in the San Antonio segment of the Edwards aquifer, 1996-2006: U.S. Geological Survey Scientific Investigations Report 2010-5129, 93 p.
Texas Administrative Code, 2011, Title 30, Part 1, Chapter 213-Edwards aquifer, accessed August 24, 2011, at www.sos.state.tx.us/tac/index.shtml.

Texas Commission on Environmental Quality, 2011, Edwards aquifer protection program, accessed August 24, 2011, at http://www.tceq.texas.gov/ field/eapp.

Texas Commission on Environmental Quality, 2006, Potential sources of contamination database.

By Martha L. Jagucki, MaryLynn Musgrove, Richard J. Lindgren, Lynne Fahlquist, and Sandra M. Eberts

\section{Contacts}

Sandra Eberts, Team Leader (614) 430-7740, smeberts@usgs.gov

Richard Lindgren, Groundwater-Flow Modeling (210) 691-9232, lindgren@usgs.gov

MaryLynn Musgrove, Geochemistry (512) 927-3522, mmusgrov@usgs.gov

For more information on the NAWQA topical study of contaminant transport to public-supply wells (TANC), see

http://water.usgs.gov/nawqa/ 